\title{
IES
}

\section{WHAT HAS BEEN THE TAX COMPETITION EXPERIENCE OF THE LAST 20 YEARS?}

\author{
Rachel Griffith \\ Alexander Klemm
}




\title{
WHAT HAS BEEN THE TAX COMPETITION EXPERIENCE OF THE LAST 20 YEARS?
}

\author{
Rachel Griffith and Alexander Klemm \\ Institute for Fiscal Studies and University College London
}

February 2004

\begin{abstract}
This paper describes tax reforms in OECD countries over the last 20 years and how they are related to tax competition. Both individual countries' reforms and multilateral initiatives and developments are covered. This is followed by an overview of the empirical evidence on tax competition. Our conclusion is that the evidence for some interdependence in tax setting behaviour is strong, although the exact process driving this remains unclear. While the most basic tax competition models fail to explain the development in OECD countries, there is more than one possible explanation for the reforms undertaken if more advanced models are considered. The multilateral initiatives that were implemented however do not seem to be related to resource-based tax competition, instead they are about taxing rights.
\end{abstract}

Acknowledgements: This work draws heavily on joint work with Michael P. Devereux to whom the authors are grateful for many discussions. The authors are grateful to Jim Hines for helpful comments. The work was funded by the International Tax Policy Forum and the ESRC Centre for the Microeconomic Analysis of Public Policy at the IFS. Responsibility for errors remains the authors'.

Correspondence: aklemm@ifs.org.uk; Institute for Fiscal Studies, 7 Ridgmount Street, London, WC1E 7AE UK. 


\section{Executive Summary}

This paper describes tax reforms in OECD countries over the last 20 years and how they are related to tax competition. Both individual countries' reforms and multilateral initiatives and developments are covered. This is followed by an overview of the empirical evidence on tax competition.

The paper begins by describing stylised fact about the evolution of taxes over the past few decades following Devereux et al. (2002): statutory tax rates have fallen; tax bases were broadened, particularly during the eighties; effective tax rates, which capture the impact of the tax rate and base on the return from an investment, fell for profitable projects, but remained fairly stable for projects that just break even or make low profits; tax revenues from corporate income have remained broadly stable as a proportion of GDP since 1965; tax revenues from corporate income have declined as a proportion of total tax revenue since 1965, but have remained relatively stable since 1980.

These complex patterns cannot be explained by most of the basic tax competition models. More advanced models, which for example allow firms to earn positive rents, can provide explanations. Because several alternative models yield very similar empirical predictions, it is however empirically difficult to test which one is driving the developments. The multilateral initiatives that were implemented however do not seem to be related to any model of resource-based tax competition. Instead they appear to be about the enforcement of taxing rights, even when claiming otherwise.

A broad reading of the empirical literature on the interdependence of tax-setting authorities suggests that some such interdependence does exist, particularly between local and national governments. Data limitations however raise some questions about the robustness of these findings. We conclude that there is likely to be some interdependence even if the exact process remains unclear. 


\section{Introduction}

Globalisation and increased capital mobility are a much-discussed topic. Despite some dissenting views, most observers agree that the interdependence between countries and the importance of the economic links between them has reached an extent unprecedented in history.

One of the fears often expressed in the context of globalisation is that the mobility of multinationals may put pressure on governments to reduce corporate income taxes in order to remain attractive for the location of capital. The most pessimistic view is that this will lead to a "race to the bottom" with extremely low, possible zero corporate income taxes. But are these scenarios realistic?

Economic theory has much progressed from the first models of tax competition (Zodrow and Mieszkowski 1986, Wilson 1986) on which this stark prediction rests. There is now a wide body of literature offering diverging predictions, depending on the type of tax competition studied and the assumptions made. ${ }^{1}$ While the view that capital mobility puts downward pressure on corporate income taxes is more widely held than the opposite view, there is little consensus on whether this is beneficial, harmful or irrelevant to economic welfare.

It is thus important to study the empirical evidence. Casual observation seems to support the hypothesis that countries compete, as statutory tax rates have fallen in most industrialised countries over the past few decades. Occasionally these tax cuts were accompanied by statements specifying that they had been in response to competitive pressures. ${ }^{2}$ Many tax reforms, however, have been more complex than simple reductions

\footnotetext{
${ }^{1}$ See Wilson (1999) for a survey.

${ }^{2}$ E.g. in its Budget 2000, the Canadian government stated that "In recent years, many industrialized countries have either reduced their corporate tax rates or announced their intention to lower them. If no action were taken, Canada's general corporate tax rate would not be competitive with those of our trading partners. The Government's objective is to reduce, within five years, the federal corporate income tax rate to 21 per cent from 28 per cent” (Department of Finance Canada, 2000). In the UK, the Chancellor of the Exchequer stated in his 1997 budget speech, "I want the United Kingdom to be the obvious first choice for new investment. So I have decided to cut the main rate of corporation tax by 2 per cent from 33 per cent to
} 
of the tax rate. In this paper we discuss tax reforms in OECD countries in more detail. We confirm the observation that most countries have lowered tax rates on corporate income and broadened tax bases. Interestingly tax revenues from corporate income have remained fairly stable, both relative to GDP and total tax revenue during the reforms.

Apart from changing their own tax system, countries may respond to competitive pressures multilaterally. There have been several such initiatives. While some of the initiatives have been implemented, none of the more ambitious ones aiming to restrict the sovereignty of setting tax rates were successful.

It is useful to begin by clarifying the meaning of a few terms. By "capital mobility" we mean that productive activity can be shifted at low cost across countries. It is important to note that capital need not actually move, the possibility that it can is sufficient. This means that it can be difficult to find evidence for capital mobility. One indirect way is to compare rates of return across countries, the idea being that corporate mobility will equalise these. However, rates of return may differ because of many factors which it can be difficult to control for, e.g. country-specific risks or a home-bias to investment. While there is some evidence in the other direction ${ }^{3}$ on balance it seems that the mobility of capital must have increased, due to the abolition of capital controls in most countries, the increasing number of free trade agreements ${ }^{4}$ and the foundation of the World Trade Organization.

“Tax competition” can refer to many different processes. We use it to describe the phenomenon that countries lower their corporate income taxes in order to attract the real activities of firms. There is also competition for taxing rights, i.e. competition for having profits reported in a particular country, without any associated movement of production.

31 per cent, the lowest ever rate in the UK. This means that we will have the lowest corporation tax rate of any of our major competitors” HM Treasury (1997).

${ }^{3}$ See inter alia Feldstein and Horioka (1980), Dooley et al. (1987) and Bayoumi (1990).

${ }^{4}$ Free trade agreements only have an indirect effect on the mobility of capital, by making it possible to produce abroad and continue selling in the home market. Note that the capital flow between countries could also decrease, because it will be less often necessary to locate abroad just to avoid tariffs. This does not however constitute a reduction in capital mobility as the term is most often used by economists and in this paper, because the cost of moving capital has not increased. 
Whenever we refer to the latter in this paper, we will clarify this by using the term competition for "paper profits" or "taxing rights".

This paper is structured as follows. In the following section we summarise the development of corporate income taxes in OECD countries over the last 20 years. This includes a discussion about whether reforms may have been driven by tax competition, and how tax revenues have evolved. In section 3 we discuss multilateral policy initiatives and their success so far. In section 4 we provide a summary of the empirical evidence of tax competition. Section 5 briefly concludes.

\section{Tax reforms and levels of taxation in OECD countries}

The theoretical literature on tax competition generally distinguishes between mobile and immobile factors. In order to study how tax reforms compare to the theoretical predictions we need to distinguish between taxes on mobile and immobile factors. This is not easy. We start with the assumption that capital is generally more mobile than labour. This is generally true, although there are some exceptions, e.g. for some types of highly skilled labour. It leads however to the question: what are taxes on capital?

One approach, developed by Mendoza et al. (1994) and widely applied (e.g. Eurostat 1999), is to consider all taxes that are not formally levied on consumption or labour income to be taxes on capital. This is likely to be too broad a category though. It includes for example taxes on land, an immobile factor. We focus on corporate income taxes. This may also include some taxes on immobile activity - not all types of business have the option of operating internationally. However, an increasingly large share of activity is mobile, including even the provision of some services as evidenced, e.g. by the increase in the use of call centres located abroad. While multinationals pay many taxes other than corporate income taxes, these are likely to be the most important ones at the margin. Note also that while corporate taxes are levied on mobile capital, they are not necessarily incident on the owners of capital (i.e. they may not bear the effective burden of the tax). In fact, in the extreme case of perfectly mobile capital and perfectly immobile labour, the incidence of all taxes will fall on the immobile factor. 


\subsection{Corporate income tax reforms}

Numerous corporate income tax reforms were undertaken in OECD countries over the past two decades. Out of the 19 countries for which we have data all, except for Spain, now have a lower tax rate than in $1982 .{ }^{5}$ Most of these countries have not only changed their tax rate, but also other aspects of their corporate income tax systems. We can distinguish two types of reforms. First, there were a few structural reforms, which did not just change the parameters of the tax system, but instead affected the principle approach taken to corporate income taxation. Such reforms include the abolition of a split rate system in Germany and Japan and the introduction of allowances for corporate equity in Austria and Italy. ${ }^{6}$ These reforms are not analysed here. More frequent, however, were reforms that adjusted parameters of existing tax systems rather than the system itself. These include changes to the statutory tax rate or the rates of investment allowances. These reforms can be compared across countries. We do that by focussing on the key parameters of the tax system and documenting their behaviour over time.

\subsection{Common characteristics of reforms}

Devereux, Griffith and Klemm (2002) analysed the development of taxes on corporate income in EU and G7 countries over the last two decades. They find the following stylised facts:

- Statutory tax rates fell.

- Tax bases were broadened, particularly during the eighties.

- Effective tax rates, which capture the impact of the tax rate and base on the return from an investment, fell for profitable projects, but remained fairly stable for projects that just break even or make low profits.

\footnotetext{
${ }^{5}$ Although in some countries tax rates have been increased for some sectors. Ireland for example increased its manufacturing rate from $10 \%$ to $12.5 \%$ in 2003 . For all other sectors of the economy the tax rate was however cut gradually (4 percentage points per year) from 36\% in 1997 to $12.5 \%$ in 2003, so that in total this reform can be described as achieving a tax cut.
} 
- Tax revenues from corporate income have remained broadly stable as a proportion of GDP since 1965.

- Tax revenues from corporate income have declined as a proportion of total tax revenue since 1965, but have remained relatively stable since 1980.

The statutory tax rate on corporate income fell in all but one country (Spain) over the period 1982 and 2003, as shown in Figure 1. Ireland increased its manufacturing rate, but cut all other rates.

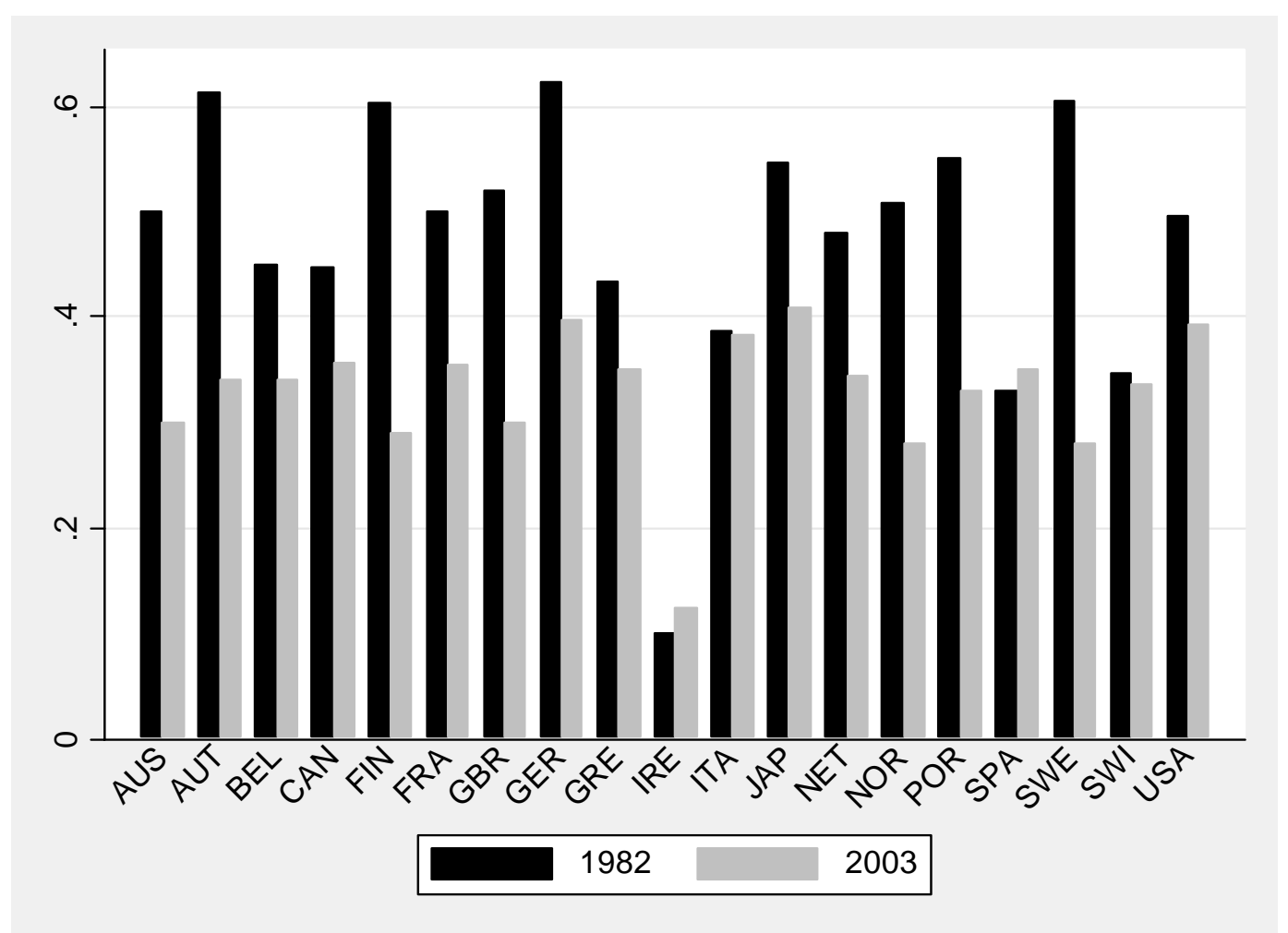

Figure 1: Statutory tax rates in OECD countries. ${ }^{7}$

${ }^{6}$ A number of countries have reformed the interaction between the corporate and personal income tax systems. Generally this was a move away from imputation and towards shareholder relief systems. An analysis of this is however beyond the scope of this paper.

${ }^{7}$ Statutory tax rates include surtaxes and local tax rates (or an average thereof). In the case of multiple tax rates, the manufacturing rate was chosen. 
To illustrate the fall in statutory tax rates further, Figure 2 shows the average statutory tax rate for most OECD countries, ${ }^{8}$ the interval obtained by adding and subtracting one standard deviation and an average weighted by GDP in US\$ are shown. ${ }^{9}$

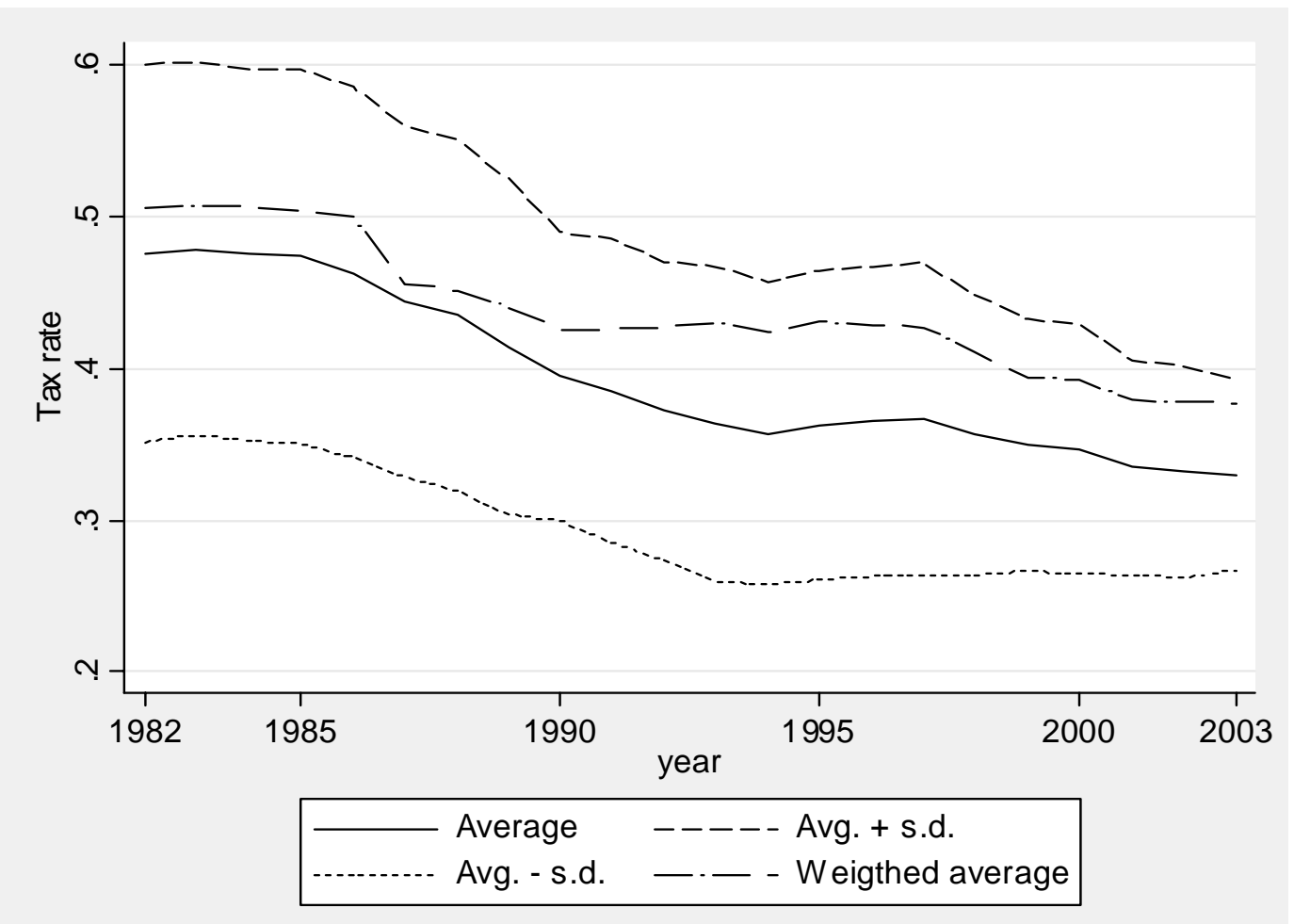

\section{Figure 2: OECD average statutory tax rates ${ }^{10}$}

There is a steeper fall in the simple average than in the weighted one, suggesting that small countries have cut their tax rates more than the large economies. Figure 2 shows the development for the five largest economies:

\footnotetext{
${ }^{8}$ We have data on the following 19 OECD countries (out of 24 member countries in 1982): Australia, Austria, Belgium, Canada, Finland, France, Germany, Greece, Ireland, Italy, Japan, Netherlands, Norway, Portugal, Spain, Sweden, Switzerland, UK and USA.

${ }^{9}$ The definition of the tax rate is less straightforward than one might think. In many countries it can be complicated to calculate a typical tax rate, because there may be regional variation in tax rates, supplementary taxes or tax credits and industry-specific rates. Our approach is to include local taxes and any other surtaxes on corporate profits. See Chennells and Griffith (1997) for details.

${ }^{10}$ Statutory tax rates include surtaxes and local tax rates (or an average thereof). In the case of multiple tax rates, the manufacturing rate was chosen. The weights used are based on GDP in US\$.
} 


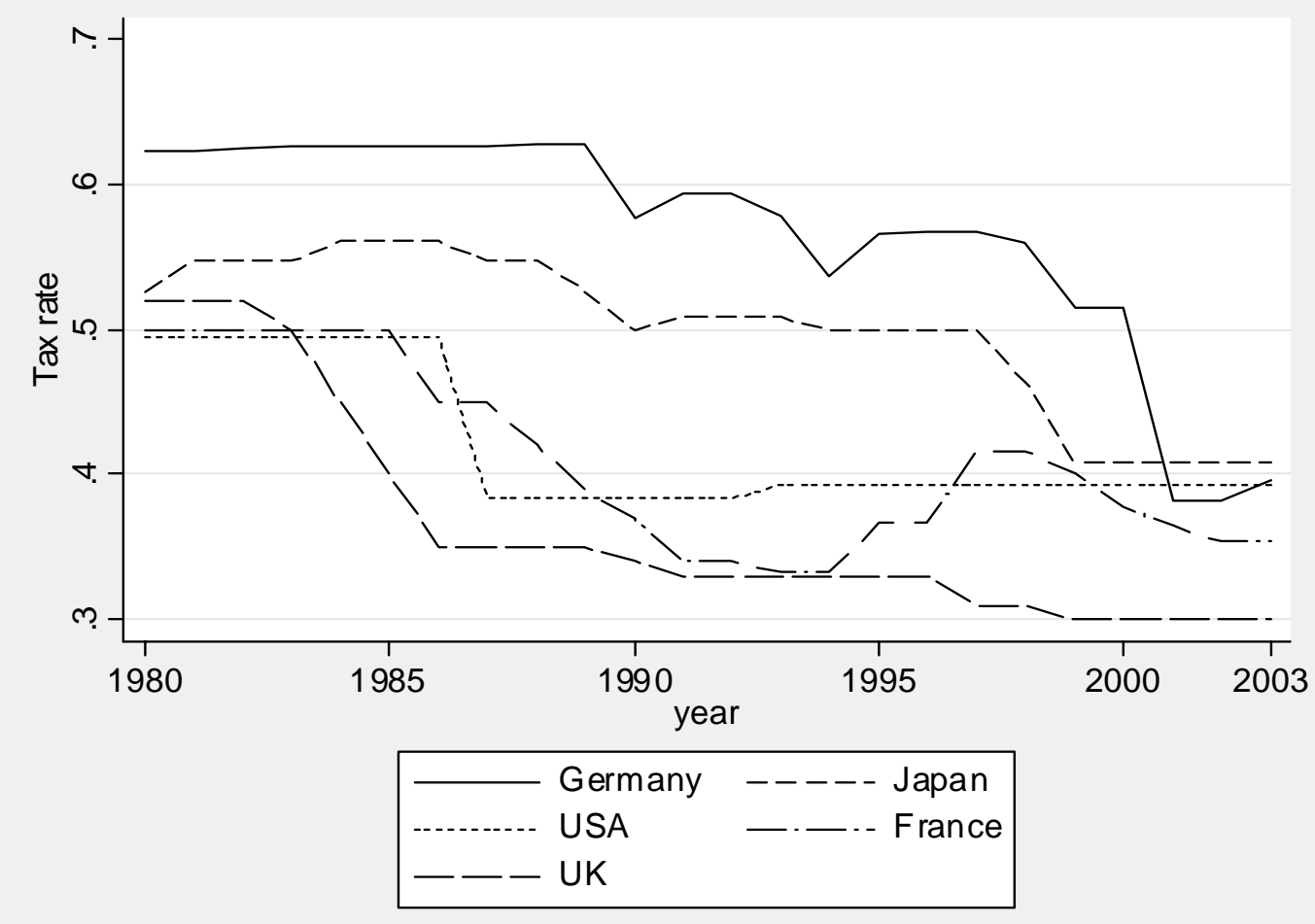

Figure 3: Statutory tax rates of the G5 economies

To illustrate the broadening of tax bases, we define a measure of the value of capital allowances for investment in plant and machinery, which is the largest component of investment for most firms. This measure will range from $0 \%$, where there are no capital allowances, to $100 \%$, where the entire cost is allowed to be written down ${ }^{11}$ for tax purposes in the year of purchase. ${ }^{12}$ This measure is strongly related to the tax base. The higher the value of allowances, the smaller the tax base. While other factors will also affect the size of the tax base, such as rules about the calculation of inventories, the deductibility of business expenses etc., the value of investment allowances is likely to be the single most important factor for its determination.

\footnotetext{
${ }^{11}$ We use the term "written down" rather than "depreciated", to distinguish between the tax treatment of the asset and the accounting treatment. In many countries the deprecation rates used by accountants in the preparation of the published accounts can differ substantially from the rate at which assets can be written down for tax purposes, although other countries require both to be the same.

${ }^{12}$ This value can exceed $100 \%$ if allowances are worth more than the asset. This can occur e.g. with investment in R\&D, which in many countries receives a particularly favourable treatment.
} 


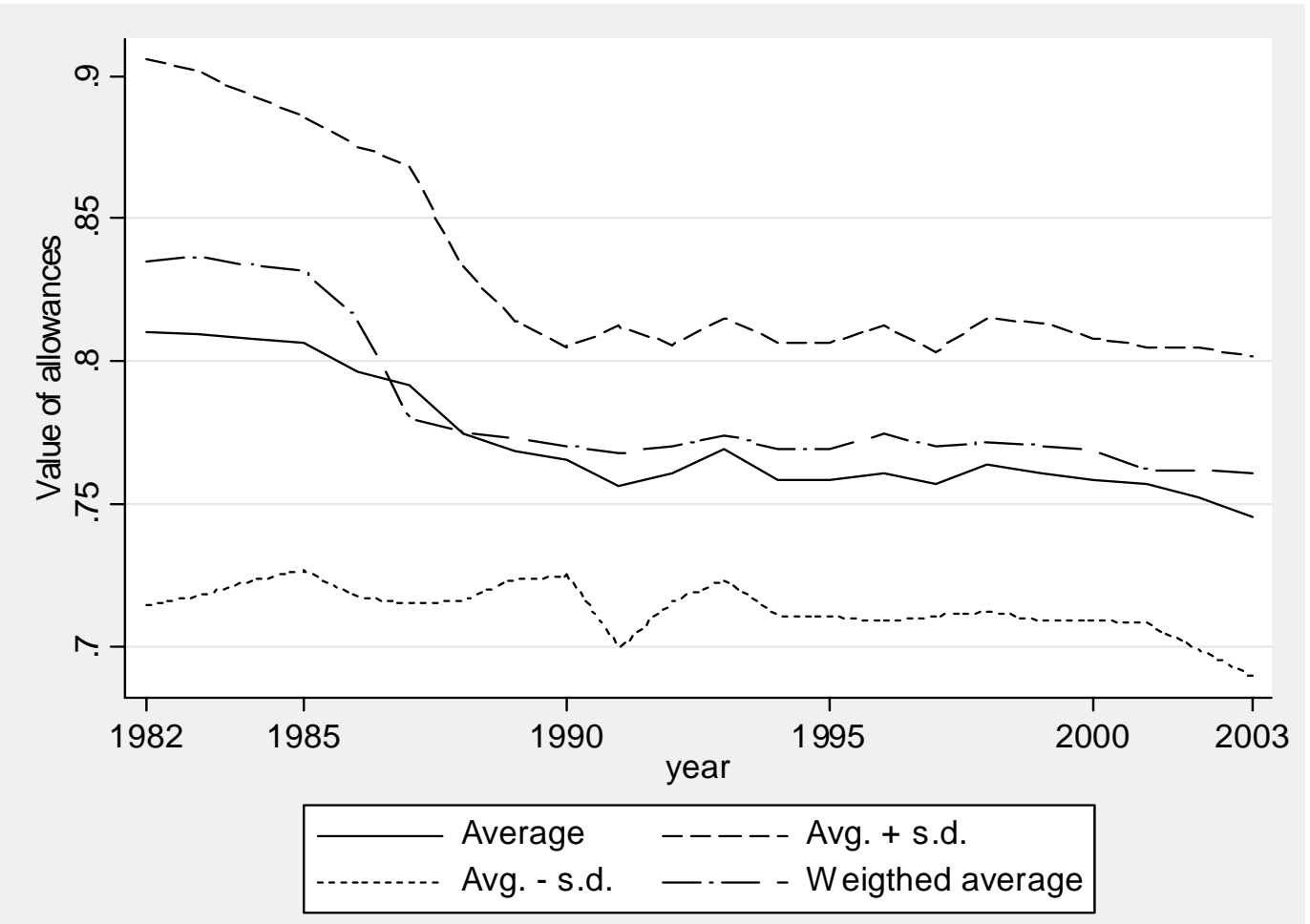

Figure 4: OECD average value of investment allowances for plant \& machinery ${ }^{13}$

Figure 4 shows the fall in tax allowances. Most of this occurred in the late eighties. The dispersion of allowance rates across countries also decreased substantially.

Figure 5 again shows measures for the five largest economies. The reduction was particularly strong in the UK where allowances were cut from 100\% to 25\%. Most countries reduced allowances by less than that, Japan left them unchanged and Germany reduced them only very recently.

\footnotetext{
${ }^{13}$ The value of allowances assumes an inflation rate of $3.5 \%$, a real discount rate of $10 \%$ and economic depreciation rates for plant and machinery of $12.25 \%$. The average is weighted by GDP in US\$.
} 


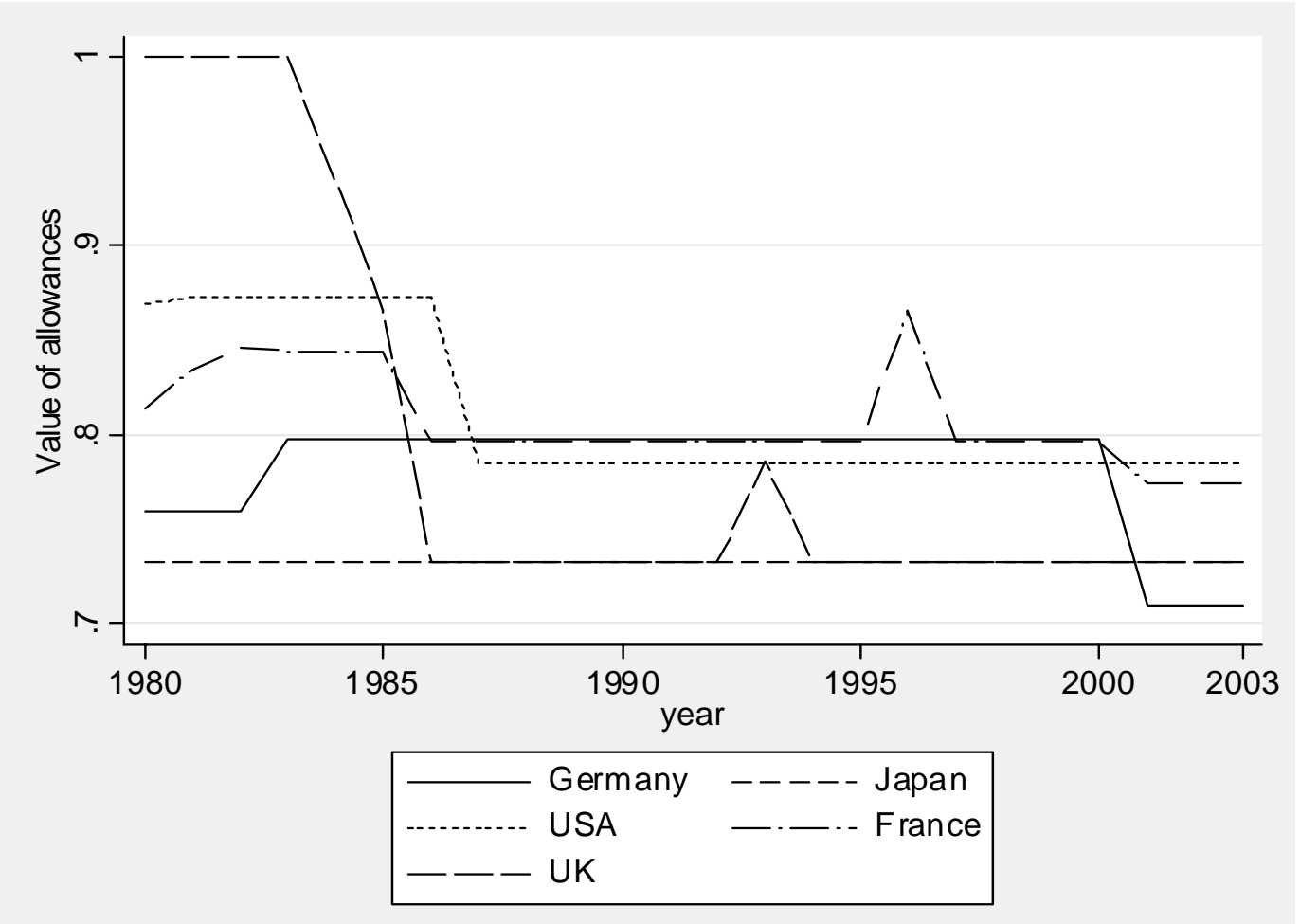

Figure 5: The value of capital allowances in G5 countries. ${ }^{14}$

In theory it is ambiguous whether the net effect of a tax rate cut combined with basebroadening will reduce or increase average tax rates faced by firms. This will depend on a number of firm-specific characteristics. First, because investment allowances depend on the assets invested in, firms will be affected differently depending on their asset structure. Second, because of interest deductibility and dividend taxation, this will depend on the sources of finance a firm uses. Third, because of the non-linearity of the tax system, it will depend on how profitable a firm is. A firm whose profitability is low will mainly benefit from generous allowances, because the value of allowances will correspond to a large share of their profit. A highly profitable firm, earning not only normal economic profits, but also rents, will benefit more from low tax rates. The allowances, which are fixed, will make up a smaller share of their profits, but the low tax rate will be applied to

\footnotetext{
${ }^{14}$ The value of allowances assumes an inflation rate of 3.5\%, a real discount rate of $10 \%$ and economic depreciation rates for plant and machinery of $12.25 \%$.
} 
their total profits. Effective tax rates measure the net effect taking different parameters of the tax system and firm-specific characteristics into account.

Effective tax rates are forward looking measures that are based on the tax laws. As tax laws can differ across industries and can depend on assets invested in and sources of finance used, and because non-linear tax systems imply that tax rates vary with profit rates, there are in theory infinitely many effective tax rates. ${ }^{15}$ We present two typical examples of effective tax rates, one for a project that just breaks even (known as the effective marginal tax rate, or EMTR) and one for a project with a positive rate of economic profits of $20 \%$ (an example of an effective average tax rate or EATR). Both assume that the project is equity financed and that the investments is in plant and machinery. We keep the inflation rate fixed in order to focus on changes in the tax law. For a discussion of the impact of relaxing these assumptions see inter alia Devereux, Griffith and Klemm (2002) or for the UK, Devereux and Klemm (2004).

${ }^{15}$ Other factors affecting effective tax rates are whether firms are tax exhausted, whether firms are multinational, and what tax treaties apply etc. 


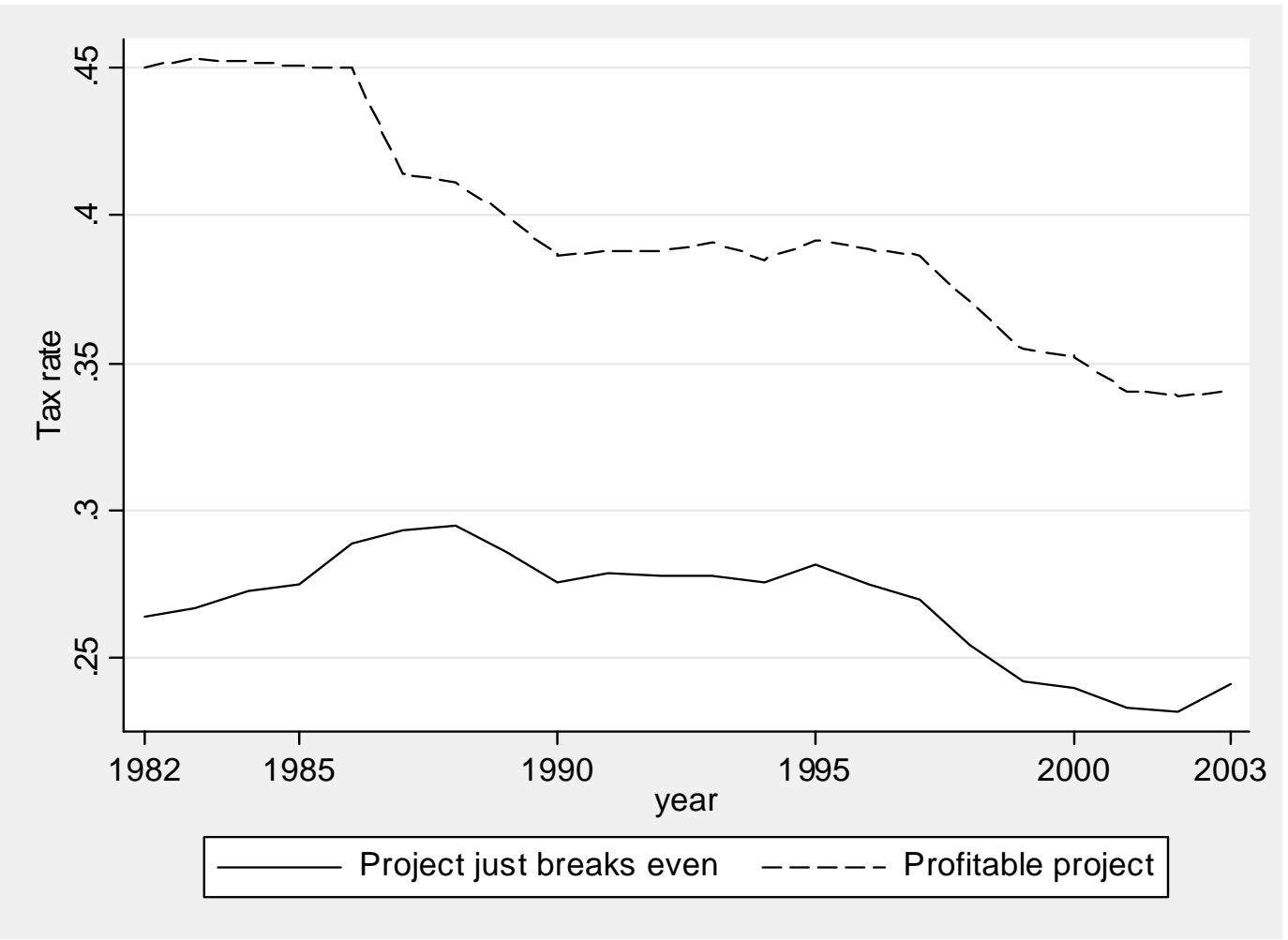

Figure 6: Average effective tax rates ${ }^{16}$

As shown in Figure 6, effective tax rates have fallen, suggesting that the net effect of base-broadening and rate-cutting was to lower taxes. Effective tax rates have fallen much more for highly profitable projects. ${ }^{17}$

\subsection{The link to theory}

Can the stylised facts described above be explained by tax competition theory? The generally predicted fall in tax rates certainly seems in line with most models that predict a downward trend in taxes on mobile factors of production. However, tax models generally

\footnotetext{
16 This figure assumes an investment in plant and machinery financed from equity (i.e. retained earnings or new equity). Shareholder level taxes are not included. Assumed inflation rate of 3.5\%, real discount rate of $10 \%$ and economic depreciation of $12.25 \%$. For the EATR the assumed economic profit rate is $20 \%$ (implying a nominal profit of 30\%). The average is weighted by GDP in US\$.

${ }^{17}$ Varying most of the assumptions does not affect these findings. However, for purely debt-financed projects, the effective marginal tax rate has risen.
} 
do not distinguish between different aspects of tax systems, such as bases and rates, but assume that a single rate applies to all capital assets.

One of the few papers that does differentiate between bases and rates is Haufler and Schjelderup (2000). They argue that countries with relatively high tax rates will want to reduce allowances to mitigate the effect on income shifting. An exogenous reduction in the cost of income shifting would have a similar effect as a high tax rate: it would make income shifting more attractive and hence lead to base broadening. This is consistent with the findings described above.

Devereux et al. (2002) argue that another possible explanation for the observed trends is that countries might be particularly interested in attracting highly profitable investment such as those performed by multinationals. In order to attract such firms, governments will have to reduce statutory tax rates. In order to limit the revenue cost, they might then reduce allowances. As these are less relevant for highly profitable investments, they are less likely to drive away FDI of multinationals.

So, while most economic models do not distinguish between tax bases and rates, there are still two alternative explanations for the observed behaviour. Which of them is more important remains unclear.

\subsection{Revenue effects}

Having discussed tax reforms and their possible motivations, we now address the question of what effect these reforms have had on corporate income tax revenues. The general reduction in tax rates might lead one to guess that the reforms should have led to lower tax revenues. However, many reasons why this may not be the case include the changes in the tax base, changes in economic activity, such as the rate of incorporation, the growth and profitability in the incorporated sector of the economy, and the distribution of types of investment. Whether or not tax revenues increased is thus an empirical question.

It should be noted that revenue figures need to be interpreted with care. Not only are they affected by many non-tax factors, as mentioned above. They are also backward looking measures, as tax revenues are affected by past legislation and events. An example of the 
former are grandfathering clauses. An example of the latter are losses brought forward. These have the effect of increasing tax revenues in the year losses are made (compared to the case of a symmetric tax system), and decreasing tax revenues in the following years, while they are being used up. Therefore data for a single year are not very informative about the level of taxes in a country. It is however possible to learn something from revenue figures when observing trends over the longer term.

In this paper we will consider two simple measures of corporate tax revenues: corporation tax revenues as a share of GDP and total tax revenues. The main other measure used in the literature is an implicit tax rate on capital as developed by Mendoza et al. (1994). As stated above, one problem of that measure is that the category "capital" is too broad for our purposes here. An equivalent implicit tax rate for the corporate sector has been suggested (Devereux and Klemm, 2004), but requires data that are difficult to obtain for a large group of countries. We thus restrict ourselves here to the simple ratios, bearing in mind that they will depend on the size of the corporate sector in the economy. ${ }^{18}$

${ }^{18}$ See also OECD (2001a) for a critique of tax ratios. 


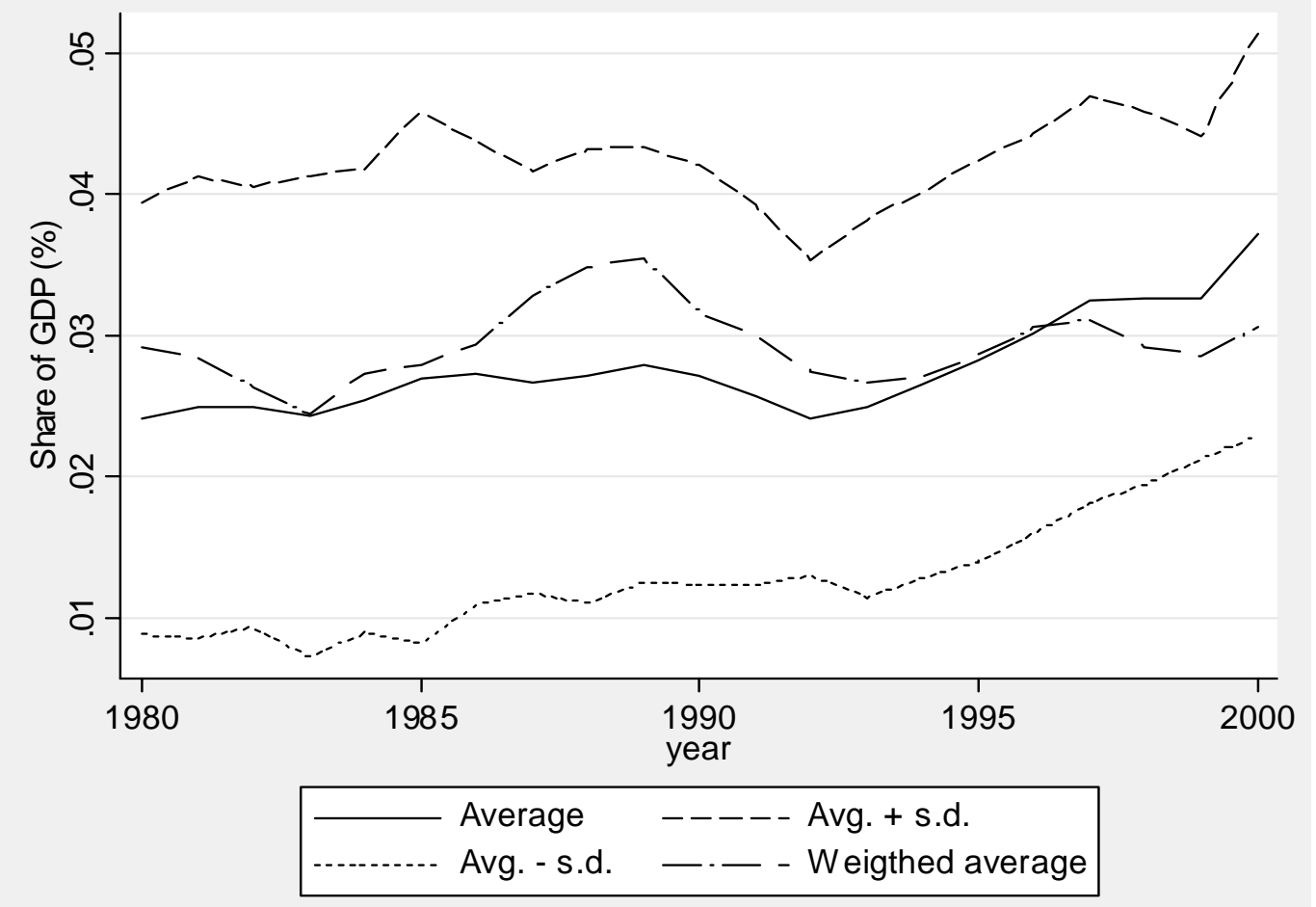

Figure 7: Corporate income tax revenues as a proportion of GDP ${ }^{19}$

Figure 7 shows corporate income tax revenues as a fraction of GDP. They have remained remarkably stable during this period of tax rate cuts. The weighted average moves with the economic cycle, but there is no discernible downward trend. The unweighted average even increases over the period, suggesting that small economies have managed to increase their revenues relative to larger economies.

If we looked at data for a single country, one explanation for stable revenues despite lower tax rates could be that the low tax rate has attracted either real activity or reported profits and thus boosted tax revenues. The averages in Figure 7 however are based on data for the OECD as whole. In that case this explanation is most unlikely to hold, as this group of countries broadly makes up the whole industrialised world, and is unlikely to have attracted much capital or reported profits from developing countries. Some shifting towards smaller low tax countries might however explain why the unweighted average increases compared to the weighted one. Overall the explanation for that pattern must

\footnotetext{
${ }^{19}$ Data from OECD Revenue Statistics, 2003 (tax class 1200). Weights based on GDP in US\$.
} 
therefore be one of the other ones given above, such as higher levels of incorporation or profitability.

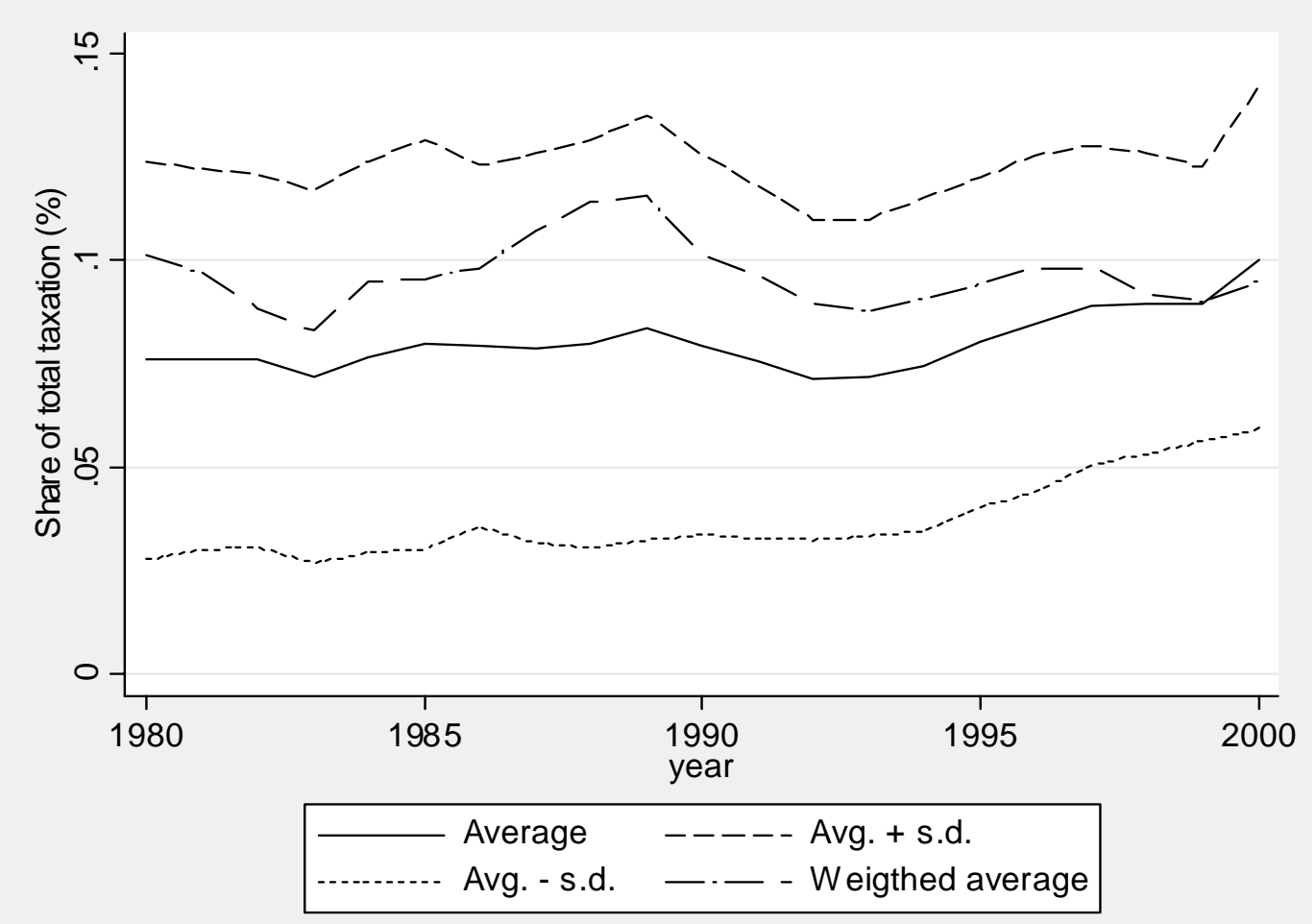

\section{Figure 8: Corporate income tax revenues as a proportion total tax revenues ${ }^{20}$}

Figure 8 shows corporate income tax revenues as a share of total taxation. Again, we see no marked downward trend, although it could be argued that the weighted average has fallen slightly, at least since the late eighties. While the current level is not below historic lows, the series has not remained at this low level for long. So arguably, while governments have managed to keep corporate income tax revenues pretty constant as a share of GDP, they have not managed to increase these revenues as much as other taxes.

It might be the case that there is not much movement, because 20 years is not a long enough time horizon. Figure 9 therefore extends the time period considered backwards to 1965. The figure also includes other important classes of taxes, along with the share corporate income taxes make up.

\footnotetext{
${ }^{20}$ Data from OECD Revenue Statistics, 2003 (tax class 1200). Weights based on GDP in US\$.
} 


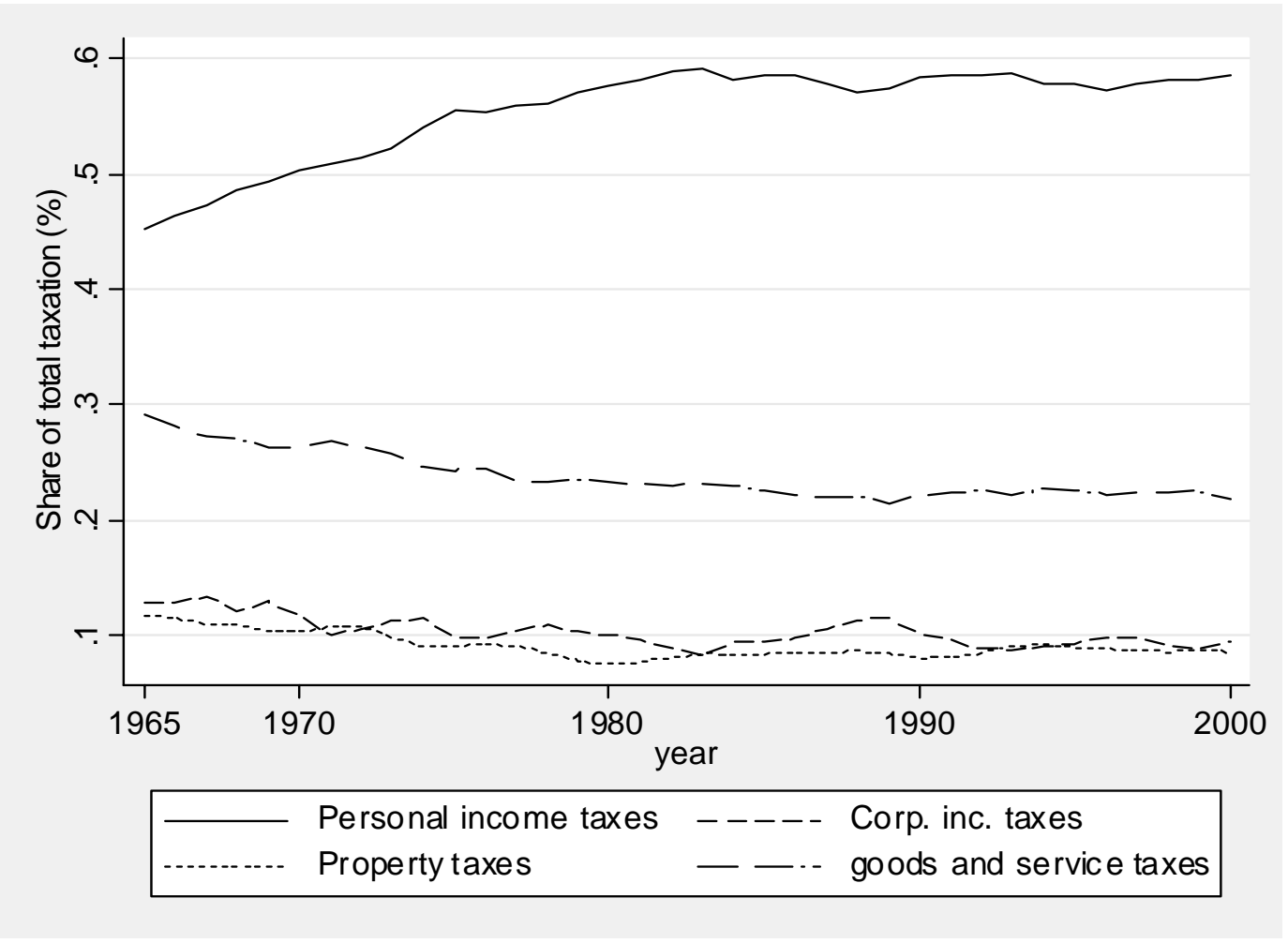

Figure 9: Major sources of government revenue as a share of total taxation ${ }^{21}$

Figure 9 shows that since 1965 the share of tax revenues from personal income taxes has increased, while all other taxes declines as a share of total revenue. By the eighties this process seems to have been completed, with only minor subsequent changes to the pattern of tax sources.

This could be seen as support for the tax competition predictions, it is puzzling why most of the changes occurred between 1965 and 1980, while capital mobility continued to increase. The European Single Market for example only came fully into effect in 1993. Possibly the early changes, such as the abolition of exchange controls were much more important that the subsequent small steps that merely aimed to improve capital mobility even further.

\footnotetext{
${ }^{21}$ Data from OECD Revenue Statistics, 2003. The taxes shown correspond to the following tax classes (in parentheses): Personal income taxes (sum of taxes on income of individuals (1100) and social security contributions (2000)), corporate income (1200), goods and service taxes (5000), property taxes (4000). Weights based on GDP in US\$.
} 


\section{Multilateral initiatives}

Having looked at tax reforms generally, this section focuses on multilateral initiatives and international developments that affect the interdependencies of international tax systems. The main multilateral initiatives were undertaken by the OECD and the European Commission. In the EU, individual countries are not only affected by new initiatives and evolving laws, but also by the interpretation of existing EU law by the European Court of Justice (ECJ). We will address to what extent European law may restrict individual countries' choices for tax reform, and how in many cases it forces them to change their existing national laws.

\subsection{OECD initiatives}

The major multilateral initiative outside the EU was initiated by the OECD. In principle OECD initiatives have the potential advantage that they cover a greater range of countries including virtually all industrialised ones. Any measure at the European level will always suffer from the flaw that the important economies of North-America and Japan are not included. However, because the OECD Council can only decide unanimously, it is unlikely that any initiative necessitating a major change in any member country's tax system would be adopted.

The OECD has undertaken an initiative against "harmful” tax competition. In the OECD context, harmful tax competition includes practices in member countries, but also those of "tax havens". For the first purpose, a harmful tax practice is defined as one with no, or nominal, effective tax rates and with a lack of effective exchange of information, lack of transparency, or ring-fencing. For tax havens, the definition is the same, except that the last criterion, ring-fencing, is replaced by lack of substantial activity taking place in the country. Note that simply having a tax rate of zero is not sufficient, if this is applied transparently and indiscriminately. 
The first result of the OECD work was the publication of a report on harmful tax competition in 1998 (OECD, 1998). Based on that report the Council of the OECD ${ }^{22}$ recommended that member countries implement the recommendations included in the report, mainly to remove the listed harmful regimes by mid-2003. The Council further instructed the Committee on Fiscal Affairs to establish a Forum on Harmful Tax Practices. This forum has since reported twice on the progress made (OECD 2000, 2001b). It also maintains a list of uncooperative tax havens. This was initially made up of 34 jurisdictions, but many of them agreed to co-operate and some were re-evaluated, so the list has dwindled down to only six ${ }^{23}$ remaining tax havens.

One of the issues that remains unclear about this initiative is the question of what the consequences of non-compliance will be. So far the Forum has been rather silent on progress on member states' harmful regimes, which should have been abandoned by now. In the case of tax havens, the 1998 report recommends not renewing tax treaties with them, but whether this is a strong threat is unclear. In the 2001 update, it was promised that any co-ordinated defensive measure would not be applied to tax havens any earlier than to member states. It thus remains a question of what form such measure might take and when they might be applied.

In conclusion, the OECD initiative seems to be mainly about the prevention of revenue erosion to tax havens or into special regimes within member countries. It has less to do with tax competition as usually thought of by economists, as there are not plans to limit the general design of tax systems, as long as they are transparent and exchange of information is in place.

\section{2. $\quad E U$ initiatives}

The initiatives at the European level cannot be understood without first considering some of the institutional background of the European Union. EU treaties to date have not

\footnotetext{
22 Switzerland and Luxembourg abstained (but did not use their veto), which implies that the Council decision is not binding on them. Belgium and Portugal abstained from the 2001 progress report.

${ }^{23}$ Andorra, Liechtenstein, Liberia, Monaco, the Marshall Islands and Nauru.
} 
covered direct taxation, which is left to individual member states. Member states are however restricted by the provisions of the treaties that created the single market and the economic community. The main issues of relevance are that the free movement of capital must not be compromised and that firms or nationals from other member states must not be discriminated against. Direct taxation remains one of the areas not covered by majority voting, so that any directives or regulations can only be passed if there is unanimity.

While an extreme interpretation of the treaty provisions would lead to the conclusion that it is impossible to keep separate tax systems, ${ }^{24}$ the general view is that tax systems can be kept different, as long as there are provisions to avoid double-taxation, and as long as firms are taxed the same in the source country. Tax harmonisation is therefore not an automatic process that will follow from the enforcement of current EU law. Instead it requires new legislation or voluntary agreements.

Some insights into how priorities and aims have changed over time can be gained by looking at the history of initiatives. ${ }^{25}$ The first time much attention was paid to this issue was in the Neumark report of 1962, which concluded that tax bases should be harmonised in order to simplify the system. The European Commission published two memoranda in 1967 and 1969, the first of which made again the case for base harmonisation, while the second argued in favour of rate harmonisation. In 1975 the Commission attempted an “Action Programme” of numerous initiatives aimed at corporate taxation (1975), doubletaxation (1976) and dividend taxation (1978). However, despite these numerous attempts, no initiative was successful other than in raising awareness for these issues. From 1990 onwards there was a change of strategy and the Commission started less ambitious but more focussed initiatives. This led to successful introduction of three measures ${ }^{26}$ to avoid double-taxation. Thereafter an independent review under the chairmanship of Onno Ruding was commissioned, the result of which was a suggestion to harmonise tax rates to a very limited degree by introducing a minimum rate of 30\% (European Commission,

\footnotetext{
${ }^{24}$ This is because any difference in tax rates will be a barrier to investing in a country with higher tax rates, as firms would prefer to simply export to that country.

${ }^{25}$ A more detailed account of the initiatives is given in Chetcuti (2001).

${ }^{26}$ The Merger Directive, Parent-Subsidiary Directive and Arbitration Convention.
} 
1992). Interestingly, this suggestion, which seemed very modest at that time, as only Ireland had a lower rate, would now be rather hard to implement. Currently there are four countries below that level (Finland, Ireland, Portugal and Sweden) and a further three exactly at the level (Denmark, Luxembourg and the UK), which shows how fast tax systems are evolving.

Because of the difficulty of implementing changes in an area where unanimity is required, a new approach was taken in 1997. This new approach was to use voluntary measures rather than legislation. The first, and so far only such measure, was the adoption of a code of conduct on business taxation. This code was adopted by the Council in 1997 (Council of the EU, 1998) and is aimed against "harmful" tax competition. "Harmful" is taken to mean preferential tax treatment to a subgroup of firms. It is very similar to the part of the OECD initiative that concerns member states. The process was first to stop introducing new measures ("stand-still") and then to abolish existing ones ("roll-back"). This was achieved by a committee, which examined potentially harmful tax regimes. Interestingly, most of the ones considered harmful, had little to do with allocation of capital, and were instead more about taxing rights. ${ }^{27}$ The final date for roll-back was 2003, but for some measures this was subsequently extended to 2010. However, it is not clear how this can be enforced, as the code does not provide for sanctions.

The latest initiative was a report (European Commission 2001a) and a communication (European Commission 2001b) by the Commission in 2001. The proposal was once again base harmonisation, however this time with the aim of introducing formula apportionment to deal with the increasing difficulties caused by transfer pricing. Even though some observers may interpret these proposals as a step towards future harmonisation of tax rates, there is no direct connection between the introduction of formula apportionment and rate harmonisation. In any event, it is doubtful to what extent, if at all, the 2001 proposals will be implemented.

\footnotetext{
27 E.g. tax advantages for the shipping industry were considered acceptable, because necessary in an internationally competitive environment. Many regimes in financial services were considered harmful, e.g. Belgian co-ordination centres, even though these hardly affect the allocation of real capital.
} 
In conclusion, while the European Commission has been very active in this area, relatively little has been achieved so far. This is unlikely to change in the future, unless majority voting were to be introduced for direct tax matters.

\subsection{The role of the $\mathrm{ECJ}$}

In recent years companies have taken governments to court claiming that national tax laws were breaching European law, particularly the European Community Treaty (EC Treaty) ${ }^{28}$ and its non-discrimination provisions. This development is different from the initiatives described above, as it is not driven by policy. Instead it results from the increased willingness to take governments to court and from the court's interpretation of the EC Treaty.

Most national tax systems are discriminatory with respect to transactions with foreign countries. This is not surprising, as much more tax is generally at stake than in the case of purely domestic transactions. To limit the possibility that multinationals report profits where taxes are lowest, most countries use a range of legislative measures. These include transfer pricing legislation, which prescribes the use of arm's length prices for international transactions between related parties. Other examples are thin capitalisation rules (disallowance of excessive debt) and controlled foreign corporation (CFC) regimes. Many countries also limit certain benefits to domestic taxpayers, particularly when they are aimed at achieving a domestic policy goal. Examples include tax credits, e.g. for $R \& D$, reduced tax rates for small companies and relief for losses of domestic companies of a group.

A strict interpretation of the EC Treaty would imply that most of these rules are contrary to European law and must be repealed or amended. There are clearly two ways to achieve conformance with European law. Either beneficial rules can be extended to apply to all EU firms or they can be repealed even for domestic ones. Both of these options come at a cost though.

\footnotetext{
${ }^{28}$ Also known as Treaty of Rome. This treaty came into force in 1958 and was subsequently amended a number of times. It is now constitutes one of the three pillars of the European Union Treaty.
} 
A recent consultation on corporate tax reform in the UK (HM Treasury/Inland Revenue, 2003) has shown that the UK's policy seems to be to reduce domestic benefits rather than extending them to cover transaction within the EU. Specifically, this consultation proposes to extend transfer price regulation to domestic transactions. While this would make the system non-discriminative, it is a proposal which otherwise has no benefit. It will increase compliance and administrative costs, but have very limited effects on tax revenues. Non-discrimination would thus be achieved by increasing the costs of domestic transaction. $^{29}$

Gammie (2003) lists four main areas in which current and future ECJ judgements are likely to influence national tax policy. First, dividend taxation is likely to move away from imputation systems, because such systems lead to a preference for investment in home country shares and for a preferential treatment of domestic shareholders. This could be avoided by paying tax credits across borders and providing relief for dividends received from abroad, but these options are very costly. In fact a number of member states, including Germany and the UK, have already dismantled their imputation systems. Second, residence-based taxation is likely to become increasingly difficult, as the concept of residence of pan-European firms will be less and less meaningful. Some schemes to ensure residence-based taxation, such as CFC legislation, are by nature discriminatory and therefore likely to be ruled out. Third, and related to the previous point, exemption systems are likely to replace credits systems. While these are not prohibited as such, it might be difficult to run them in a way that is at the same time administratively practical, competitive and EU-law compliant. Fourth, transfer pricing legislation is less likely to be enforceable, although the recent consultation in the UK (see above) suggests that member states are willing to accept high administrative and compliance costs in order to be able to keep such legislation.

The previous discussion suggests that ECJ judgements may lead to fundamental changes of national tax systems. The ECJ however only plays a negative role, in that it can only rule against national provisions. The effect this has on tax competition is unclear. To the

\footnotetext{
${ }^{29}$ A further discussion of this and a list of other UK tax legislation that may be in breach of the EC Treaty are contained in Bond and Klemm (2003).
} 
extent that national measures aimed at preventing such competition are ruled out, this process could lead to more competition. A co-ordinated response by member states would be possible, but this cannot be achieved by the ECJ, which merely ensures that the EC Treaty provisions are heeded.

\section{Empirical evidence on competition}

Having discussed tax reforms and multilateral initiatives, we now summarise the growing empirical literature on tax competition. Two main approaches are taken in the literature. Some papers study the issue indirectly, e.g. by looking for the responsiveness of investment to tax rates. Other studies use direct empirical evidence. This can be done at the sub-national level, e.g. between federal states, or across countries. While crosscountry studies are more relevant for the purposes of this paper, it is also useful to look at within-country evidence, because there has been much more work using such data. Furthermore such studies have the advantage that many data comparability problems or problems of unobservable heterogeneity can be assumed away.

\subsection{Indirect Studies}

The main approach of indirect studies is to estimate the sensitivity of firms to changes in tax regimes. This allows conclusions to be drawn about tax competition: if there is evidence that such sensitivity is strong, then this would suggest that rational welfaremaximising governments would either engage in tax competition, or set taxes cooperatively. There are several recent surveys of this sort of indirect evidence. Hines (1999) reviews this literature and concludes that the allocation of real resources is highly sensitive to tax policies. De Mooij and Ederveen (2001) similarly conclude that foreign capital is very sensitive to tax using meta analysis. Devereux and Griffith (2002) discuss

these findings and the literature on which they are based. They conclude that, while there is some evidence that taxes affect firms' location and investment decisions, it is not clear how big this effect is. They also note that the literature has provided little by way of insight into the key questions for policy interest. Linking the (reduced form) estimates 
from this literature to the (structural) parameters in a model of tax competition is very difficult, and has not been done satisfactorily. Thus, while we can conclude that tax policy is important, we are unable to say very much from these indirect studies on any more specific policy questions. Neither can these findings prove that there is a process of tax competition. All they show is that a pre-condition for such a process is fulfilled.

\section{2. $\quad$ Direct Studies}

\section{(a) Preliminary methodological remarks}

Direct evidence can be obtained by estimating the interdependence in tax rates between jurisdictions. ${ }^{30}$ This is usually done by estimating whether one jurisdiction's tax rate reacts to a change in the tax rate in another jurisdiction. Even though countries are not directly affected by each other's tax regimes, the amount of a resource (generally capital) that resides in their country will depend on all countries' tax rates. If they compete for this resource using the tax system, then we can expect to find interdependence in tax systems. Apart from this resource-based competition, there are however other processes that would equally lead to interdependence. If evidence of interdependence is found, we therefore cannot conclude that this must have been driven by tax competition.

An alternative explanation for interdependence in tax setting behaviour between countries is yardstick competition or tax mimicking. In this model voters judge the performance of the government by comparing their tax rates to the ones in neighbouring countries. This clearly also leads to interdependence in tax setting.

Yardstick competition is one form of direct spillover. More generally fiscal spillovers can occur if tax and spending decisions by a government in one jurisdiction also affect residents in a neighbouring jurisdiction. For example, if one country uses taxes to reduce pollution this may have positive benefits to residents of neighbouring jurisdictions and result in interdependent tax setting.

\footnotetext{
${ }^{30}$ See Brueckner (2003) for an overview of empirical studies.
} 
Finally, related movements in tax rules could also be caused by a common factor driving tax reforms in all countries, such as common intellectual trends. A specific example would be an influential study on the optimal choice of corporate tax rates of which economic advisors in many countries become aware. In that case one would see simultaneous tax reforms even in the absence of any competitive process. The ratelowering base-broadening reforms of the past two decades for example might not have been caused by tax competition but instead by a common desire and understanding of the importance of simple and fraud robust tax systems.

Because of this observational equivalence, i.e. that different models imply the same predicted behavioural response, it is necessary in empirical work to provide additional justification if any particular interpretation is made. For example, Besley and Case (1995) show that voters' support for incumbents is related to the taxes of neighbouring states. This lends support to their interpretation of interdependence as indicative of yardstick competition. This sort of evidence can often be difficult to provide in practice. However, for policy formation it is crucial that we understand which model is driving behaviour.

\section{(b) Within country direct studies}

A number of papers have looked at competition at the sub-national level. In most cases the approach is to look at interdependence across local governments, although some papers also study the interdependence between local governments and the central government. These studies suggest support for all three forms of tax competition.

Case, Rosen and Hines (1993) find evidence of interdependence between US States due to public expenditure spillovers while Fredriksson and Millimet (2002) find evidence to suggest that there are spillovers due to pollution abatement.

Revelli (2002) finds evidence against the tax-spill-over model, but cannot discriminate between the resource-flow and yardstick competition models using English municipal data on property taxes. A number of papers are based on the resource flow model, which is of most interest to us here. Most of them however do not explicitly test it against the yardstick competition model. Empirical papers include the following: Brueckner and Saavedra (2001) find strategic interaction for property taxes in cities in the Boston metropolitan area; Brett and Pinske (2000) obtain similar results using business property 
taxes of municipalities in British Columbia (Canada); Buettner (2001) finds interdependence for local business tax across German municipalities. Hayashi and Boadway (2001) find more evidence of interaction of provincial corporate taxes with the central government's tax than across provinces in Canada; Esteller-Moré and Solé-Olé (2002) study Canadian income taxes and find evidence of interdependence across Canadian provinces, that this is mitigated by the presence of equalisation grants and they find interdependence between provinces and the central government.

A paper that specifically finds evidence of yardstick competition is Besley and Case (1995) using income tax data for US States.

\section{(c) International direct studies.}

More recently empirical work has turned to international tax competition. Chennells and Griffith (1997) consider specific predictions from the tax competition literature and look at whether the empirical evidence supports them. They calculate effective and implicit tax rates for ten countries over the period 1979-1994. They then consider whether small countries have lower taxes than larger countries, ${ }^{31}$ whether this depends on the degree of openness, and whether capital importing countries set their tax rates at, or below, a dominant capital exporter. ${ }^{32}$ None of these hypotheses are supported by the data.

Devereux, Griffith and Klemm (2002) present evidence on the development of taxes on the income from capital since the mid 1960s. They find that effective tax rates on marginal investments have remained fairly stable as a result of rate-cutting basebroadening reforms. Effective tax rates on more profitable investments however have fallen substantially. As more profitable capital is often also the more mobile capita, this can be interpreted as competition for mobile capital, particularly that employed by multinationals (see above). They cannot however rule out an alternative explanation, e.g. countries trying to discourage the shifting of paper profits, as modelled in Haufler and Schjelderup (2002).

\footnotetext{
${ }^{31}$ See, inter alia, Bucovetsky (1991) and Wilson (1991).

${ }^{32}$ See, inter alia, Gordon (1992).
} 
There are only two papers that the authors are aware of that directly address the question of whether there is empirical evidence to suggest that countries engage in tax competition for mobile capital.

Devereux, Lockwood and Redoano (2001) use an updated version of the data in Chennells and Griffith (1997) and estimate countries' reaction functions. The strength of this paper is that the authors pay careful attention to measuring forward-looking effective tax rates. The weakness is that, in order to do this, they limit themselves to ten countries over a relatively short time period, and can only look at taxes on specific types of corporate investment. They find evidence to suggest that there is interdependence in the statutory and average tax rates, but not in marginal tax rates. They interpret this as evidence in favour of tax competition. The authors are not able to provide any supporting evidence to distinguish between the various models (resource flows, yardstick, spill-overs or other common factors).

Besley, Griffith and Klemm (2001) estimate the interdependence in tax setting behaviour amongst OECD countries. The strength of this paper is that it considers a larger number of countries and five tax bases (labour, corporate, property, sales, excise), which vary in the degree of mobility. The drawback is that, in order to look at so many countries and such a range of taxes, the authors have to use backward looking average tax rates. The paper tests two hypotheses that arise from the tax competition literature: (i) that taxes on more mobile factors should be more interdependent, (ii) that interdependence should be greater between countries where there is greater mobility (e.g. the EU). They find evidence in favour of these hypotheses. While it is still difficult to distinguish between the various models, we could interpret the fact that the degree of interdependence on different factors is related to their mobility as evidence in favour of the resource flows model.

Finally, a paper by Bretschger and Hettich (2002) should be mentioned. Their paper in a way combines the indirect and direct approaches, as it analyses the effect of the openness of the economy on an implicit corporate income tax rate. Unlike most previous work, they control for the fact that small countries always appear to be more open, when their trade is expressed as a share of national income. They find that more open economies 
have lower tax rates, supporting a tax competition model. Yardstick competition in this set up is much less likely.

Summing up the direct evidence, it seems that the existence of some interdependence in tax rates is now a relatively robust finding. The process driving this remains unclear though. While some papers produce evidence in favour of or against one of the possible mechanisms, at least for a specific tax, we still cannot confidently conclude which process is the most relevant in driving corporate income tax interdependence.

\section{Comments and Summary}

What do we conclude from this discussion?

There are a number of stylised facts about the evolution of taxes over the past few decades: statutory tax rates have fallen; tax bases were broadened, particularly during the eighties; effective tax rates, which capture the impact of the tax rate and base on the return from an investment, fell for profitable projects, but remained fairly stable for projects that just break even or make low profits; tax revenues from corporate income have remained broadly stable as a proportion of GDP since 1965; tax revenues from corporate income have declined as a proportion of total tax revenue since 1965, but have remained relatively stable since 1980 .

There are a number of difficulties in looking for direct empirical evidence on national governments' tax setting behaviour. Several alternative models yield very similar empirical predictions, distinguishing between them is difficult. The data needed to do this is not readily available. The indirect evidence is not much better. It is very difficult to draw direct implications about tax setting behaviour from the literature on the impact of tax on firms' behaviour.

From a broad reading of the literature one could conclude that the evidence points to some form of interdependence between tax setting behaviour across local and national governments. However, even this finding can be questioned at the country level due mainly to problems with the data used. Distinguishing between different reasons for this interdependence is simply not possible from the current state of the literature. 


\section{References}

Bayoumi, T. (1990) “Saving-Investment Correlations: Immobile Capital, Government Policy or Endogenous Behaviour” IMF Staff Papers, 37(2), 360-387.

Besley, T. and A. Case (1995) "Incumbent behavior: Vote Seeking, Tax Setting and Yardstick Competition” American Economic Review 85, 25-45

Besley, T, R. Griffith and A. Klemm (2001) “Empirical evidence on fiscal interdependence in OECD countries” Institute for Fiscal Studies mimeo

Bond, S.R. and A. Klemm (2003) "Corporation tax reform: a response to the government's August 2003 consultation document” IFS Briefing Note No. 40 (www.ifs.org.uk/corptax/bn40.pdf)

Bretschger, L. and F. Hettich (2002) “Globalisation, capital mobility and tax competition: theory and evidence for OECD countries” European Journal of Political Economy, 18, 695-716

Brett, C. and J. Pinkse (2002) “The determinants of taxes in British Columbia” Canadian Journal of Economics, 33-3, 695-714

Brueckner, J (2003) "Strategic interaction among governments: an overview of empirical studies” International Regional Science Review, 26-2, 175-188

Brueckner, J. and L.A. Saavedra (2001) “Do local governments engage in strategic property-tax competition?” National Tax Journal 54-2, 203-230

Bucovetsky, S. (1991) “Asymmetric Tax Competition” Journal of Urban Economics, 30, $167-181$

Buettner, T. (2001) "Local business taxation and competition for capital: the choice of the tax rate” Regional Science and Urban Economics, 31, 215-245

Case, A., Rosen, H. and Hines, J. (1993) "Budget Spillovers and Fiscal Policy Interdependence: Evidence from the States” Journal of Public Economics, 52, 285307

Chennells, L and Griffith, R (1997) Taxing Profits in a Changing World, London: Institute for Fiscal Studies

Chetcuti, J.-P. (2001) “The process of corporate tax harmonisation in the EC” Lex EScripta Online Legal Journal.

Council of the European Union (1998), "Conclusions of the ECOFIN Council Meeting” Official Journal of the European Communities, C2, 6.1.1998

Department of Finance Canada (2000) “Budget 2000 - Five-year Tax Reduction Plan”, Toronto: Department of Finance.

Devereux, M, Lockwood, B and Redoano, M (2001) “Do Countries Compete over Corporation Tax Rates?” University of Warwick mimeo

Devereux, M.P., R. Griffith and A. Klemm (2002) “Corporate Income Tax Reforms and International Tax Competition” Economic Policy 35. 
Devereux, M.P. and R. Griffith (2002) "The impact of corporate taxation on the location of capital: a review”, Swedish Economic Policy Review 9, 79-102

Devereux, M.P. and R. Griffith (2003) "Evaluating tax policy for location decisions” International Tax and Public Finance, 10, 107-126.

Devereux, M.P. and A. Klemm (2004) "Measuring Taxes from Income on Capital: Evidence from the UK”, in P.B. Sorensen (ed.) Measuring the Tax Burden on Capital and Labour, MIT Press, Cambridge (MA), forthcoming.

de Mooij, R.A. and S. Ederveen (2001) "Taxation and foreign direct investment: a synthesis of empirical research”, CPB Discussion paper No. 3.

Dooley, M., J. Frankel and D.J. Mathieson (1987) “International capital mobility: What do the savings-investment correlations tell us? IMF Staff Papers, 34(4), 503-530.

Esteller-Moré, A. and A. Solé-Olé (2002) “Tax setting in a Federal System: the case of personal income taxation in Canada” International Tax and Public Finance, 9, 235257

European Commission (1992) "Report of the Committee of Independent Experts on Company Taxation”, Office for Official Publications of the European Communities, Luxembourg

European Commission (2001a) “Company Taxation in the Internal Market”, Commission Staff Working Paper SEC(2001) 1681 final

European Commission (2001b) “Towards an Internal Market without Tax Obstacles” Communication from the European Commission COM(2001) 582 final

Eurostat (1999) "Structures of the Taxation Systems in the European Union" Luxembourg: Office for Official Publications of the European Communities.

Feldstein, M. and C. Horioka "Domestic Savings and International Capital Flows" Economic Journal, 90(358), 314-329.

Fredriksson, P. and Millimet, D. (2002) "Strategic Interaction and the Determinants of Environmental Policy Across US States” Journal of Urban Economics, 51-1, 101-122

Gammie, M. (2003) “The role of the European Court of Justice in the development of direct taxation in the European Union”, Bulletin for International Fiscal Documentation, 57(3), 86-98.

Gordon, R.H. (1992) “Can capital income taxes survive in open economies?” Journal of Finance, 47, 314-329.

Haufler, A. and G. Schjelderup (2000) “Corporate tax systems and cross country profit shifting” Oxford Economic Papers, 52, 306-325.

Hayashi, M. and R. Boadway (2001) “An empirical analysis of intergovernmental tax interaction: the case of business income taxes in Canada” Canadian Journal of Economics, 34-2, 481-503

Hines, J. R. (1999), “Lessons from behavioural responses to international taxation”, National Tax Journal, June, 305-22 
HM Treasury (1997) “The Chancellor’s 1997 Budget Speech” HM Treasury, London.

HM Treasury/Inland Revenue (2003) "Corporation tax reform - A consultation document”, London: The Stationary Office.

Mendoza, E.G, Razin, A. and Tesar, L.L. (1994) "Effective tax rates in macroeconomics: cross country estimates of tax rates on factor incomes and consumption" Journal of Monetary Economics, 34, 297-323.

OECD (1998), “Harmful Tax Competition: An Emerging Global Issue”, Paris: Organisation for Economic Co-operation and Development.

OECD (2000), “Towards Global Tax Co-operation: Progress in Identifying and Eliminating Harmful Tax Practices”, Paris: Organisation for Economic Co-operation and Development.

OECD (2001a) “Tax Ratios: A Critical Survey” Tax Policy Studies 5, OECD, Paris

OECD (2001b), “The OECD’s Project on Harmful Tax Practices: The 2001 Progress Report”, Paris: Organisation for Economic Co-operation and Development.

OECD (2003) "Revenue Statistics”, OECD, Paris (www.sourceoecd.org)

Wilson, J. (1986) “A Theory of Interregional Tax Competition ” Journal of Urban Economics vol.19

Wilson, J. (1991) “Tax Competition with International Differences in Factor Endowments” Regional Science and Urban Economics, 21, 423-451

Wilson, J. (1999) “Theories of tax competition” National Tax Journal 52, 269-304

Zodrow and Mieszkowski (1986) "Pigou, Tiebout, Property Taxation, and the Underprovision of Public Goods” Journal of Urban Economics vol.19 